\title{
TRANSNATIONAL CORPORATIONS AND ANTI-TRADE SENTIMENT
}

\author{
Carmen Valentina R $\breve{A D U L E S C U}{ }^{a^{*}}$, Iulian GOLE ${ }^{b}$, Florentina Olivia $B \breve{A L U}{ }^{c}$, \\ Evelina Petronela B $\breve{A L} U^{d}$
}

\author{
${ }^{a, b, c, d}$ Bucharest University of Economic Studies, Romania
}

DOI: $10.24818 / \mathrm{IMC} / 2020 / 05.18$

\begin{abstract}
In addition to the health crisis, we are all witnessing, for a while, a skeptical sentiment against globalization, a certain general opinion related the internationalization of trade. After decades of continuing progression of global value chain arrangements between different economical entities or even within the same company, upward or downward the production processes, frequently in different countries or continents, today we can see there is an increasing opposition against trade competition. In some countries, immense fissures were created between labor unions and management because their interests were going in different directions. By the meaning of qualitative methods, we will analyze why this divergence is happening especially in developed countries, who are the most affected peopl, what actions may be taken by decision-makers. We also demonstrated that global value chain companies are more efficient in a free global market and putting trade barriers would have negative consequences on the entire economy.
\end{abstract}

KEYWORDS international trade, liberalization policies, value chain.

\section{INTRODUCTION}

There is almost certitude among specialists the benefits of international trade are unequally distributed between workers. As in many other areas of economic activity, international trade favors some people while others are disadvantaged. To understand this situation, it is important to answer a few research questions: whose economic well-being is affected by international trade and in which sense, what are the consequences on the social and political side. The main objective of the paper is to comprehend the efficiency of international trade and what are the reasons for change resistors. We believe it is very important also to understand what global value chains brought in international corporations, from the management point of view but also the low skills workers. It passed already few decades since many companies decided to take advantage of the low price of labor on different countries, and moved abroad their production or part of production processes. Today almost nobody trades finished goods but rather intermediate parts or services - due to the process of integration and specialization, many companies found their way to success in international trade. Due to this segmentation of production, many low-skilled workers, especially from developed countries, found them under pressure and consequently raised their voices against international trade generating an anti-globalization sentiment.

\section{CURRENT CONTEXT}

In order to appreciate the relevance of the subject, we have to take into consideration the actual political situation in many developed countries. Since 2016 when Donald Trump became president

\footnotetext{
* Corresponding author. E-mail address: carmen-valentina.radulescu@eam.ase.ro
} 
of U.S., his main engagement, to impose import penalizations on those American companies who produce outside the country, materialized in complete abandon of Trans-Pacific Partnership (TPP), a renegotiation in force of the North American Free Trade Agreement (NAFTA), a general tariffs trade war with China and even against Europe, for specific industries.

The same issue was present on the political agenda in Canada as well, even though at a different level. Despite the fact of promoting a "progressive trade agenda”, Trade Minister Chrystia Freeland, considered that globalization and technology revolution was good for a narrow elite but not for most of the people. As a result, among other political decisions, the government launched talks with China and the renegotiation of NAFTA. In Europe, we didn't really see a willingness to renegotiate international trade agreement but once the economic consequences of pandemic crises appeared, many politicians claimed the EU should create a strong autonomy from China (for medical products). This demand was recently generally accepted within the EU but is coming after a long period of labor syndicate fights against international corporations to relocate certain sites of production in countries with lower wedge price. France is the best example; here trade unions having a long tradition and being one of the strongest voices.

In fact, the core of the discussion is if international companies should be blamed for their profit maximization attitude by producing more offshore and therefore for reducing jobs in developed countries. The international trade prosecutors are right from a historical perspective, according to Pierce \& Scott, in the U.S. there was a massive loss of manufacturing jobs since 1950 , from $30 \%$ to nearly $8.5 \%$. Of course, it is well known there was a normal shift from manufacturing to service jobs which is normal until a certain point but few U.S. states have lost around 1249100 jobs from the manufacturing sector (most of them in computer and electronic parts industry but also in textiles, apparel, and furniture) during 2000-2013 and these were quite decisive in the election. Among them, according to Kimball, W. \& and Scott, we can name California, Texas, Oregon, Massachusetts, Minnesota, North Carolina, New Hampshire, and Vermont. It is not a coincidence the fact that China entered the World Trade Organization in 2001. Even though international trade is responsible only for a part of this loss, there were some researches (Autor et al., 1996) proving that the situation is due to massive import stocks from China, a normal consequence of the battle between an organized labor force and a liberal economy with open policies.

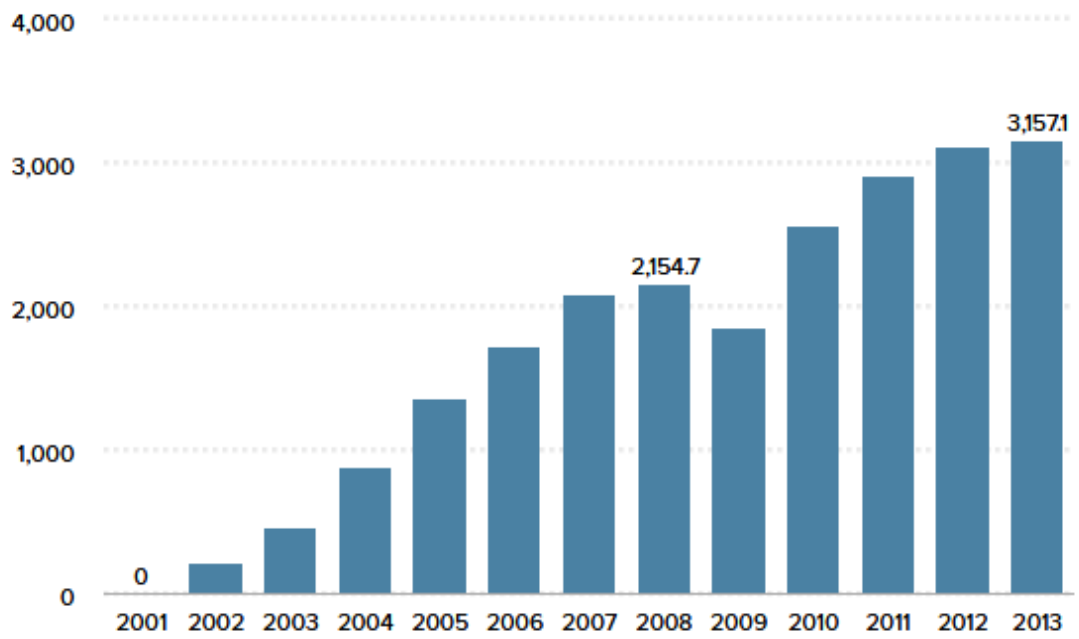

Figure 1. Number of U.S. jobs displaced by the trade deficit with China, 2001-2013, Source: U.S. Census Bureau (2013), (in thousands of jobs).

During the entire analyzed period, except for of 2009, 3157100 jobs were lost. On average, 287 000 jobs / year have been lost or displaced. On the other hand, we also witnessed a certain change in the capitalist manager's attitude during the time since now they are much open to free trade 
comparing with normal workers, contrasting with the post-war decades when everyone was in favor of barriers against imports. Those times, when coalitions between workers and managers were feasible are gone, since today there is no production exclusively realized within the company, the global value chains being efficiently internationalized. The main reason for managers to move parts of intensive labor production outside the country was to substitute the expensive local workers with cheap foreigners. Despite the additional price that a company has to pay (building new factories and infrastructures, training, import taxes, and other barriers) many managers became supporters of policy liberalization in order to allow their offshore produced goods to return on local markets without extra taxes. Competition with low labor cost from China was lost from the beginning; starting with 2001 many low-skilled U.S. workers lost their jobs and somehow their demands of protection fuelled the anti-internationalization of trade sentiment. From here to become antiglobalization supporters was just another step, so it is somewhat understandable the rise of political polarization especially in U.S. society, but in other countries as well.

\section{TRADE AND POLITICS AND THEORETICAL FRAMEWORKS}

If until some decades ago, because of high transportation and logistical costs but also to complexity in communication, companies were forced to produce internally their products, with the time, due to technological advancement, managers took the opportunity to produce outside borders or to outsource part of the production. The economists demonstrated that increased efficiency may be found if companies spread their production value chains across different countries and even companies. Many firms decided to preserve only the core of their value chain (human resource, $\mathrm{R} \& \mathrm{D}$, financial services, etc.) in the country of origin and to delocalize all the production abroad. Giving the technical possibility to connect fast and safe with foreign partners allowed extending the businesses - 2/3 of international trade is done with intermediate inputs and goods for final consumption (Johnson \& Noguera, 2012).

Having the opportunity to connect with other companies value chains in order to combine their goods and services, put firm managers to deal with new situations, since not all circumstances are similar. Depending on the company they work for, managers lobbied for different trade policies. Companies operating in import sectors with the strong foreign competition are in favor of import restrictions. In countries with abundant skill labor (U.S, E.U.), firms prefer import restrictions barriers for intensive labor sectors while in countries with labor abundant (Mexico, Bangladesh, Vietnam) companies with skill-intensive industries would make pressure for import tariffs. These preferences would definitely contribute to policy moderation. Governments are obliged to take care of overall citizen welfare but at the same time, they need political support. The stronger is the need of governments for manager influence and financial contributions the faster they will impose tariffs for import goods. In long run, the higher price will be paid in the end by final consumers. The firms which operate in exporting have opposite interest regarding barrier trade; they need easy access to low price labor in order to become competitive in the international market. Favoring export or import companies, governments have to find a trade-off between political support and national welfare.

While local value chain firms (producing and operating in the local country) would like policymakers to defend trade restrictions, the global value chain companies are in favor of rather total trade liberalization (not only import but also export). The productivity of such enterprises was proved to be greater since they could connect with the best suppliers and resources and would have cheap access to a global market. Economists calculated that in the case of Indian and Indonesian firms, a reduction of $10 \%$ of tariffs would bring a $12 \%$ productivity gain (Topalova $\&$ Khandelwal, 2011). In a theoretical model, we will explain hereafter why developing a global value chain is more efficient for a company and for the entire global economy. 


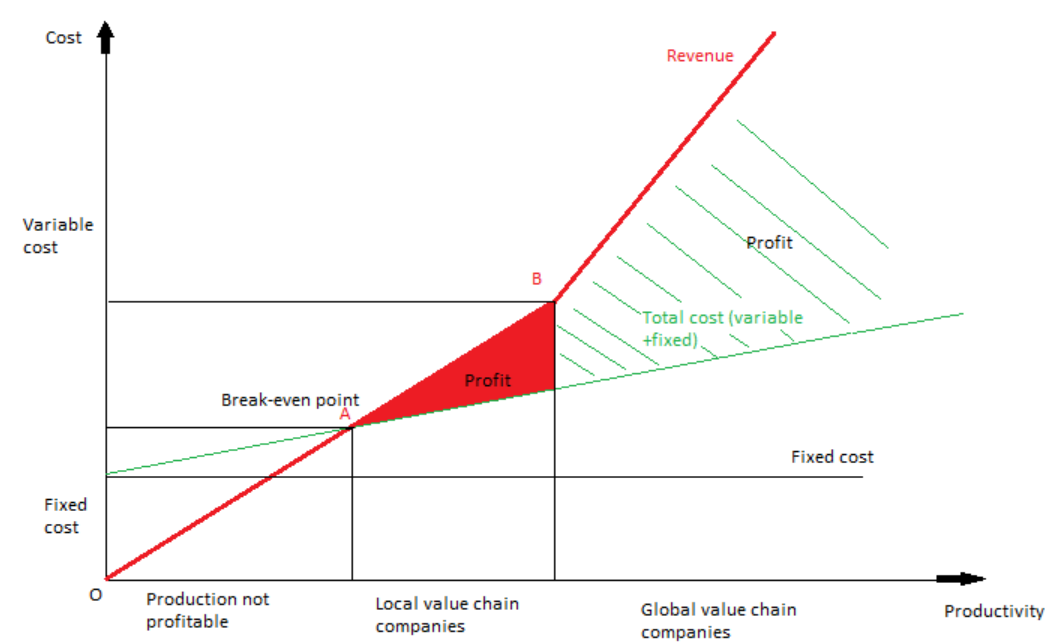

Figure 2. Interdependency between local and global value chain firms.

Source: Adapted from “BREAK_EVEN ANALYSIS”, Chandra Sekhar, 2020.

It is well known that in order to produce any goods or services, every company will have to pay fixed costs that do not change with an increase or decrease of production like lease and rental payments, insurance, etc. While the revenue doesn't cover at least the fixed cost, any firm, regardless if they have a local or global value chain, cannot start the production. The moment when fixed costs and variable costs (raw material, salaries, etc.) reached the revenue level it means that the firm reached the breakeven point -A. Starting from this level all local and small companies, with global value chain, will start to produce, making a profit, until a certain level (red area) - finished in point $\mathrm{B}$, when either local firm will expand its local value chain to international level or other international companies with already implemented global value chain will take the opportunity and will enter into the market realizing greater financial gains (green lines area). From the final consumer point of view, the more competition and the broader the option to choose its products, the better for his budget. In the next picture, we can see what is happening in the case of trade liberalization tariffs.

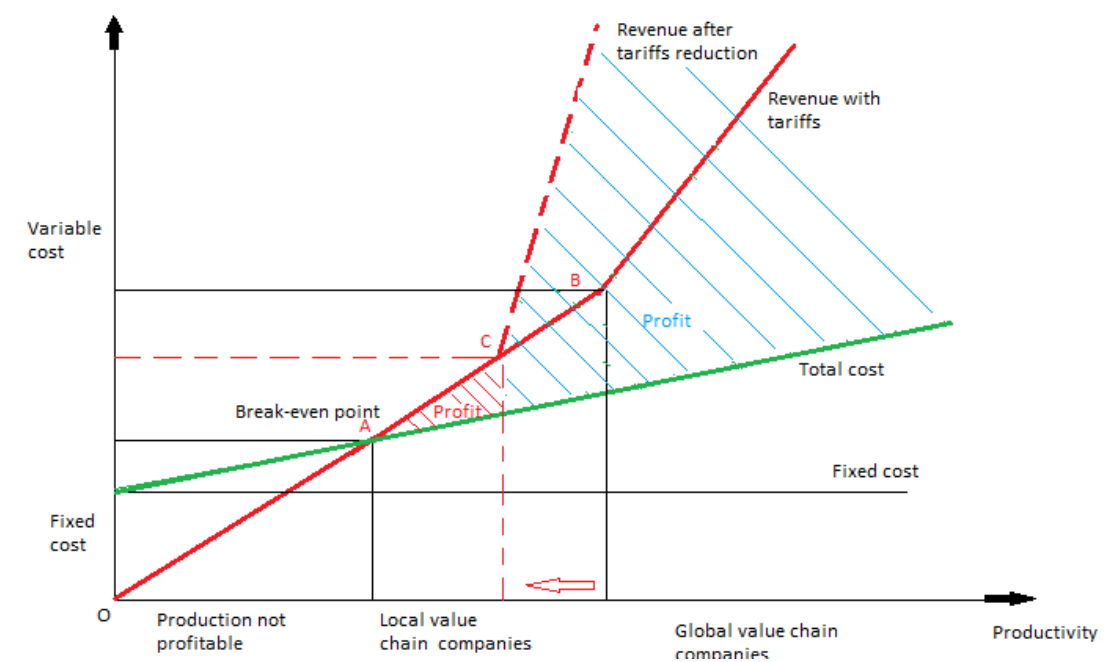

Figure 3. The effect of trade liberalization tariffs.

Source: Adapted from “BREAK_EVEN ANALYSIS”, Chandra Sekhar, 2020.

A first effect is that global value chain enterprises will benefit from a diminishing of their variable costs and therefore they will be incentivized to produce earlier, so the production will start in point 
$\mathrm{C}$ and not B as before. Not only they will enter into the market earlier but their revenue will be even higher, compared with the full tariffs situation, therefore the slope of revenues is steeper.

There is also a second effect - since the limit for global value chain forms is lowered. Due to tariffs reduction, it means also that even local value chain companies can develop globally with less effort, so they will also be incentivized to change their attitude regarding international trading business and will start to look for opportunities outside the country. We may conclude that trade liberalization affects the economic welfare and political positions of different stakeholders in various ways. Already we saw that forms are different positions regarding the reduction of trade barriers but even inside the same company, there is an opposite point of view at different levels.

Managers (especially those of global value chain firms) are totally in favor of liberalization because the benefits are higher and consequently their salaries and bonuses are more consistent. End consumers are also happy since a reduction of tariffs means lower prices and higher competition on the market. For the workers the situation is mixed: the skilled employees, those who are working on headquarter, are in a better situation since enlargement of businesses means a higher need of them so they could demand better salaries; for the unskilled employees is worse because the local production decrease which is equivalent to jobs lost and reduced salaries. At a country level, trade liberalization is equivalent with a net gain because the benefits of people who are better off exceed the losses of those who are at disadvantage. In order to avoid the pain of unskilled workers, the governments should create redistribution wealth policies, by means of taxes, but sometimes the political willing are different from social agenda and sometimes are complicated to impose.

In our theoretical explanations, we assumed that countries involved in international trade are playing a correct business game in which free market and free competition are the baselines.

In the next graphic (build from a series of data for the last 35 years, obtained from the U.S. Census Bureau) we can see that the trade deficit of the U.S. in relation to China was almost zero during the 1985-1995 period, whereupon a constant increasing path started to appear. If in 2001, the year when China entered in WTO, the deficit was 8.3 billion USD, we can see a continuing growth of exceeding imports over the exports. The process culminated in 2018 when the trade deficit was almost 420 billion USD. Before accepting China in WTO there were many voices claiming that extinction of a market would benefit all participants, including the U.S. and many jobs will be created in all participating countries, a sort of win-win situation. The reality was that China didn't play fair. By manipulating the currency, using extensive subsidies for state companies, imposing legal and illegal barriers to import, dumping, and limitation of labor rights, China became a net exporter in relation not only with the U.S. but with the entire world.

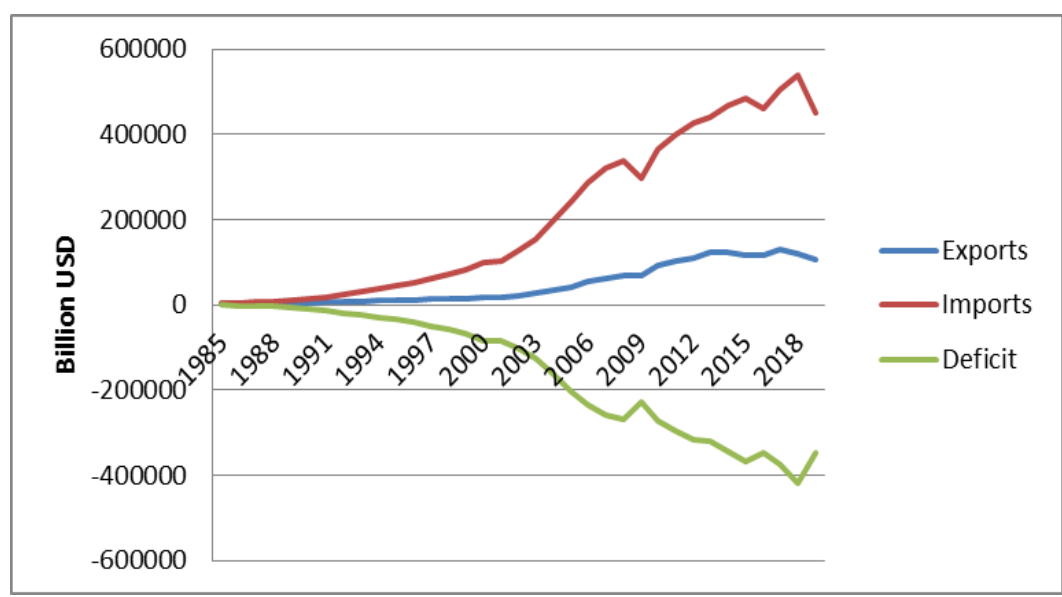

Figure 4. U.S. trade goods with China.

Source: own representation based on U.S Census Bureau data. 
The success of China exports was due also to the important Foreign Direct Investments agreement, many transnational companies being invited to invest in the local economy.

If we look in retrospective, the trade liberalization with China didn't bring too much value for the U.S. (for American employees was quite a disaster since more than 3 million jobs were lost till 2013) therefore the confrontational attitude of Donald Trump is understandable, especially if we consider that he won the election due to working-class with low wages.

But, generally speaking, a world that respects the rules of the economic game, without trade barriers, is a better world for businesses, as we can see it from the graphic below.
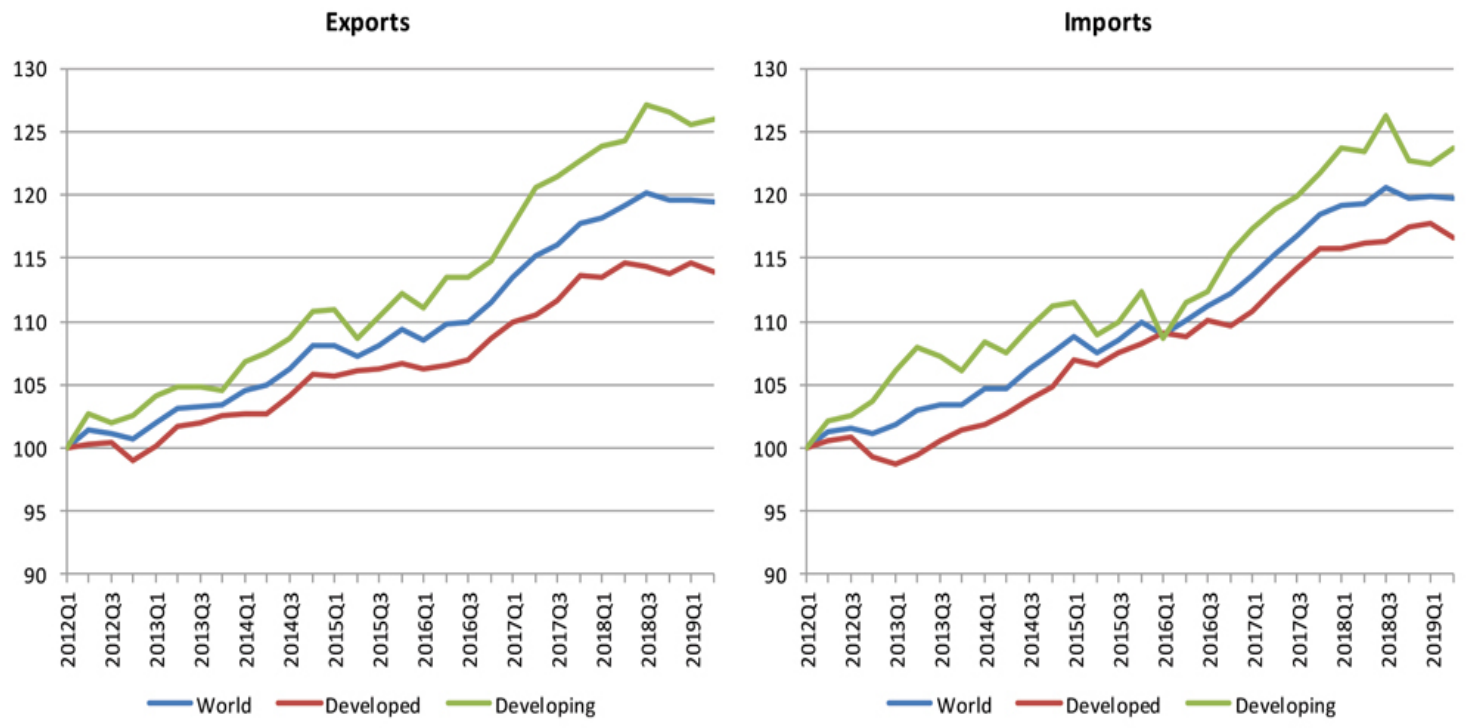

Figure 5. World goods exports and imports by the level of development.

Source: WTO and UNCTAD. 2012Q1-2019Q2. Volume index, 2012Q1=100.

During 2012-2019 we assisted in a permanent rise of import and export trade operations, which means a growing gain for all participants. If we take into consideration this reality it means that our theoretical assumptions are correct and trade barriers should be removed, under the conditions all participants respect each other and the rules of the free market.

Another issue that is related to growing trade operations is overconsumption. It is obvious that producing more and cheaper is good for the end consumer but at the same time, it incentivizes to consume more, which is great for the business but a real disaster for the planet. Among the profitability, firms should have an obligation to take into consideration the ecological aspects. Some of them are doing it already but others not at all, therefore it is important to rethink some barriers from an ecological point of view and not only from jobs or benefits perspective.

\section{CONCLUSIONS}

In this paper, we explained the reasons for the growing sentiment of anti-internationalization of trade and ultimately anti-globalization, at least in developed countries. We explained why the global value chain enterprises are better off without trade barriers and what the consequences are for local value chain firms in case of non-adaptation to the global economy. In all competing import sectors, all multinationals companies or transnational corporations took the opportunity of using cheap unskilled labor and moved their production abroad. The managers are in a natural conflict of interests with the local employees but the end consumers are in favor of internationalization trade since the prices normally will diminish. Nevertheless, their decisions of offshoring the production 
will rather help foreign workers than co-nationals therefore dissatisfaction related to trade liberalization became an important aspect that is used in political campaigns. There are also legitimate voices that raise the questions about the origin of the goods - to which extent an American company who has most of its employees abroad may still put the logo "made in the U.S.”. We showed that war tariffs started by the Trump administration against China is justified since China is the main beneficent of being a WTO member, mainly because they don't respect the free market economy practices.

We also demonstrated that overall, global value chain companies are more efficient, and putting trade barriers would have negative consequences on the global economy. The last decade was a full period of growing trade business for exporters but also for importers, in all countries.

It is obvious that trade liberalization created happy and sad people. The problem appears when the winners are always large corporations and the losers are simple workers. Trade liberalization and consequently globalization became a source of social discord, especially now, when we live in a period of job insecurity. To reconcile the opposing parts, governments tried to compensate the defeaters with social expenditures. In the same time, in few countries with less public spending control, the social cover represent a real threats for finding a job, since many people would want to accept social aid instead of working. We are living in interesting times; the UK left the EU under promising a better economic activity while the U.S. insists on the renegotiation of NAFTA. Although there is logical and technical evidence that free trade is a better solution for all, the contestant's replay is that these agreements didn't bring economic benefits as promised at the beginning by policy-makers. It seems that one way or another, the global trade will do step down, it remains to see if the future will certify if it was a good move or not.

\section{REFERENCES}

Autor, D., Dorn, D., Hanson, G., \& Song, J. (2014). Trade Adjustment: Worker Level Evidence. Quarterly Journal of Economics, 129(4), 1799-1860.

Chandra, S. (2020). BREAK-EVEN ANALYSIS: Break-even point, Determinants of BEP, Breakeven chart, Assumptions, Advantages, cases., ISBN-13: 979-8651414055, 24 pages.

Johnson, R. \& Noguera, G. (2012). Accounting for Intermediates: Production Sharing and Trade in Value Added. Journal of International Economics, 86(2), 224-236.

Kimball, W. \& Scott, R. E. (2014). China Trade, Outsourcing and Jobs. Economic Policy Institute, Briefing Paper \#385. Retrieved August 10, 2020 from https://www.epi.org/publication/chinatrade-outsourcing-and-jobs/

Pierce, J. \& Schott, P. (2016). The Surprisingly Swift Decline of U.S. Manufacturing. American Economic Review, 106(7), 1632-62

U.S. Census Bureau (2013), U.S. International Trade Commission (USITC 2014), Bureau of Labour Statistics (BLS 2014b), and BLS Employment Projections program (BLS-EP 2014a and 2014b). Retrieved from https://www.census.gov/foreign-trade/reference/codes/atp/index.html

Speech - Address by International Trade Minister Chrystia Freeland at the Conference of Montreal, June 15, 2016 - Montréal, Quebec, Retrieved from https://www.canada.ca/en/globalaffairs/news/2016/06/address-by-international-trade-minister-chrystia-freeland-at-theconference-of-montreal.html

Topalova, P. \& Khandelwal, A. (2011). Trade Liberalization and Firm Productivity: The Case of India. Review of Economics and Statistics, 93(3), 995-1009.

U.S Census Bureau (2020), Trade in Goods with China. Retrieved August 10, 2020 from https://www.census.gov/foreign-trade/balance/c5700.html\#2020 